Humanitas, 2021; 9(17): 76-100

ISSN: 2645-8837 http://dergipark.gov.tr/humanitas

DOI: 10.20304/humanitas.859601

\title{
RUMELİ DEMIRYOLLARI EGE DENIZİ BAĞLANTI HATTINDA YENİ BİR LİMAN KENTİ: DEDEAĞAÇ (1872-1912)
}

\section{H. Veli AYDIN ${ }^{1}$}

$\ddot{O} z$

$\mathrm{Bu}$ çalışma, 1872-1912 yılları arasında Rumeli Demiryollarının İstanbul-Belgrad merkez hattından Ege denizine uzatılan bağlantı noktası Dedeağaç mevkiinde inşa edilen istasyon çevresindeki boş ve 1ssız bir sahil kesiminde ortaya çıkıp, kısa sürede bölgenin modern bir liman kentine dönüşen Dedeağaç kentinin tarihsel gelişim sürecini ele almaktadır. Avrupa merkezli dünya ekonomisinin tarımsal bir imparatorluk olan Osmanlı İmparatorluğu'na liman kenti üzerinden yeni ekonomik biçimleriyle girişinin bu kentin mekânsal ve sosyal gelişimini nasıl etkileyip dönüştürdüğü ve yaşanan bu hızlı büyümenin kentin art alanı üzerindeki kadim yerleşim birimleri ile limanlar üzerindeki etkileri de ayrıca tartışılmaktadır. Ayrıca Dedeağaç’ın on yıl gibi kısa bir sürede nahiye merkezinden kendi adıyla anılan bir sancak merkezine dönüştürülmesi, İstanbul-Selanik demiryolu yapımıyla aynı zamanda askeri açıdan Osmanlı devletinin elinde kalan Balkan toprakları için nasıl stratejik bir merkeze dönüştürüldüğüne dikkat çekilmektedir.

Anahtar Sözcükler: Trakya, Dedeağaç, Aleksandroupolis, liman kenti, Rumeli demiryolları, ticaret

\section{A NEW PORT CITY ON THE AGEAN JUNCTION LINE TO THE RUMELIA RAILWAYS: DEDE-AGHAC (1872-1912)}

\begin{abstract}
This study focuses on how the city of Dede-Aghac, which emerged in an empty and deserted coastal area around a railway station in the area where it was built as a branch line to the Istanbul-Belgrade central line of the Rumelia Railways in 1872, and on its transformation into a modern port city in a short period. It is also argued that how the entry of the world economy into the Ottoman state, an agricultural empire, with its new economic forms affects the urban and social development of the city and the effects of its rapid growth on its hinterland. Additionally, it also explores how the city was transformed from the sub-district into a sanjak center and became a commercial
\end{abstract}

\footnotetext{
${ }^{1}$ Doç. Dr., Tekirdağ Namık Kemal Üniversitesi, Fen Edebiyat Fakültesi, Tarih Bölümü, vaydin@nku.edu.tr, ORCID: 0000-0001-8872-5038
} 
and military center for Ottomans with the construction of the Istanbul-Thessaloniki junction railways through the last decade of the 19th century in the Balkans.

Keywords: Thrace, Dede-Aghac, Aleksandroupolis, port city, Rumelia railways, commerce

\section{Giriş}

Günümüzde Yunanistan sınırları içerisinde yer alan ve Batı Trakya'nın önemli liman

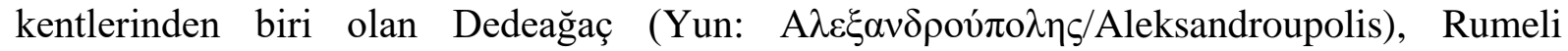
Demiryollarının İstanbul-Belgrad merkez hattının Edirne Kuleli Burgaz'dan Ege denizine uzatılan bağlantı noktası oluşturan Dedeağaç mevkiinde 1872 yılında kurulan hat ve istasyon şubesi üzerinden gelişerek kısa zamanda yeni bir liman kentine dönüşmüştür. Dedeağaç, demiryolu ve liman bağlantısı nedeniyle çok kısa bir sürede dünya ekonomisinin güçsüz Osmanlı tarımsal imparatorluğuna genişlemesine aracılık eden bir kentsel yapı olarak, Trakya bölgesinin önemli ve cazip bir ticaret merkezine dönüşmüştür. Edirne vilayeti Dimetoka sancağına bağlı bir kaza merkezi iken, 1884'te sancak ve sancak merkezine dönüşmüştür (Gökbilgin, 1991, s. 200; Keyder, 2010, s. 14). 1877/78 Osmanlı Rus savaşı sırasında Ruslar tarafından işgal edilmesi kentin ekonomik ve demografik açıdan bir süre gerilemesine neden olsa da 1896 yılında Dedeağaç-Selanik demiryolu bağlantısının kurulması Dedeağaç'ı hızlı bir şeklide kalkındırarak, yeniden gelişmesini sağlamıştır. Kent, konumu nedeniyle de Balkanların idaresi ve savunulması için stratejik açıdan önemli ulaşım ve ticaret kavşağı haline dönüşerek, Balkan Savaşlarına kadar Osmanlı idaresinde kalmıştır.

Balkan Savaşları arifesinde Dedeağaç bir sancak ve kaza merkezi olarak yaklaşık 9.000 kişilik bir nüfusa sahipti. Kentte, uluslararası ticaretteki önemli konumu nedeniyle sekiz yabancı devlet konsolosluğu ile yedi vapur şirketi temsilciliği bulunuyordu. Kentin demiryolu ve vapurlar vasıtasıyla başta İmparatorluğun başkenti İstanbul olmak üzere, Avrupa ve diğer önemli Akdeniz limanlarıyla bağlantısı bulunuyordu. Dedeağaç'ın önemli miktarda Rum ve Bulgar nüfusu barındırması, kenti Bulgaristan ile Yunanistan arasında önemli bir mücadele bölgesine dönüştürmüştür. Balkan savaşları sırasında 1912'de Bulgarlar tarafindan işgal edildi. 1913 Bükreş Anlaşmasıyla da Bulgaristan’a bırakıldı. 1918 yılındaki Neully anlaşmasına kadar Bulgaristan'ın Ege ve Akdeniz'e açılan bir limanı olarak hizmet etti. Ancak bu anlaşmayla Dedeağaç Yunanistan'a terk edildi. 1927 yılında Yunan Kralı I. Aleksanderos'un kenti ziyaretine atfen, kentin adı Aleksandroupolis olarak değiştirildi (DedeAğaç, 1978, s. 500; Tuğlac1, 1985, s. 338). 
Bu çalışma, 1871-72 yılları arasında Rumeli Demiryolları merkez hattının Edirne-Ege Denizi bağlantısını sağlamak üzere Dedeağaç mevkiine inşa edilen son istasyon çevresinde ortaya çıkan ve kısa sürede Trakya ile Bulgaristan Prensliği’nin tarımsal ürünlerinin Avrupa'ya ihraç ve Avrupa sanayi ürünlerinin bu bölgelere ithalat merkezine dönüşen yeni liman kenti Dedeağaç’ın doğuşu; kısa sürede ekonomik ve idari açılardan gelişerek Edirne vilayetinde önemli bir kaza ve sancak merkezi haline gelmesi ile demografik ve ticari açıdan nasıl önemli bir modern liman kentine dönüştügünü incelemeyi amaçlamaktadır. Araştırma, dönemin Osmanlı arşiv kaynakları, salnameler, Cervati kardeşlerin ticaret yıllıkları, kenti bu tarihlerde ziyaret eden Osmanlı ve yabancı ziyaretçilerin gözlemleri, Dedeağaç’ta bir dönem mutasarrıflık yapan Hazım Tepeyran'ın anıları ve çağdaş Yunanca kaynaklara dayanmaktadır. Çalışmada Dedeağaç’ın yeni bir liman kenti olarak art alanındaki İnöz (Ainos/Enez), Ferecik (Feres) ve Mekri (Makri) gibi kadim kentler üzerindeki olumsuz etkisine de değinilecektir. Ayrıca Türkçede kent üzerine ufak bir iki çalışma dışında ciddi bir monografik çalışmanın olmaması, olanların da büyük yanlışlar ve yetersiz bilgilerle dolu olması nedeniyle bu çalışma, Osmanlı döneminde bölgede önemli bir rol oynayan bu liman kentinin tarihiyle ilgili ciddi literatür boşluğuna ufak da olsa bir katkı sunarak, konu üzerine yeni araştırmaları teşvik etmeyi de ummaktadir.

\section{Rumeli Demiryolları ve Ege Denizi’ne Çıkış Kapısı: Dedeağaç}

Osmanlı İmparatorluğu'na demiryolları Kırım Savaşı (1853-56) sonrası bazı bölgelerde girmeye başlamıştı, ancak İstanbul'u Edirne üzerinden Balkanlar ve Avrupa'ya bağlaması düşünülen Rumeli demiryollarının Osmanlı devleti için özel bir önemi vardı. Tanzimat yöneticileri Avrupa Uyumu'na (Concert of Europe) dahil edilen Osmanlı devletinin başkentinin Avrupa'ya bir demiryolu hattı ile bağlanmasının, Avrupa ile bütünleşmede önemli bir rol oynayacağına inanıyorlardı. Bu bağlantı bir yandan Rumeli vilayetlerinde sanayi ve ticaretin gelişmesini teşvik ederken, diğer yandan bu bölgelerde meydan gelmesi muhtemel isyan ve savaşlara karşı devletin demiryolu hattı üzerinden kısa sürede bu bölgelere asker ve askeri malzeme sevk etmesine imkan sağlayacaktı (Mehmet Cavid, 1324, s. 79-80; Engin, 1983, s. 43).

Osmanlı Devleti'nin, yapmayı tasarladığı Rumeli demiryolu hattını ekonomik ve teknolojik imkansızlıklar nedeniyle kendisinin inşa etmesi mümkün olmadığından, hattın inşası için Avrupa şirketleri ve piyasasına yönelmek zorunda kalmıştır. Demiryolunun inşası için dört başarısız imtiyaz girişiminden sonra, Avusturyalı banker Baron Hirsch imtiyazı alarak, 1870 yılında inşaatı yürütecek Rumeli Demiryolları Şirket-i Şahane ile işletmeyi 
üslenen Rumeli Demiryolları İşletme Kumpanyasını kurar. İnşaat için gerekli sermaye temini için de şirketlerin tahvillerini satarak gerekli sermayeyi sağlayıp, 4 Haziran 1870’te YedikuleKüçükçekmece hattının yapım çalışmalarına başlar (Mehmet Cavid, 1324, s. 82-83; Engin, 1983, s. 61; Engin, 2008, s. 235-237).

Rumeli demiryolları hattının Osmanlı Devleti'nin Balkanlar'da Rusya'ya karşı savunma gücü ve ekonomik çıkarlarını artıracağı gerekçesiyle Avrupa devletleri de bu projeyi desteklemiştir. İstanbul'dan Viyana'ya uzanması tasarlanan ana hatta Karadeniz kıyısında bulunan Varna ile Ege Denizi Saroz körfezinde İnöz'e bağlanması çok büyük ekonomik avantajlar sağlayacaktı. Burasının Rumeli'nin diğer bölgeleriyle bağlantı sağlayacak merkezi bir konumu bulunuyordu. Yük gemileri İstanbul ve Çanakkale boğazından geçmeden yüklerini bu iskeleye bırakarak büyük ekonomik avantajlar sağlayacaktı. Benzer şekilde Karadeniz'de de Varna üzerinden yüklerini tren hattıyla nakledebileceklerdi. Bu durum Osmanlı devletinin gelirlerini artıracağı gibi bu bölgelerde tarım ve ticaretin gelişmesini sağlayacaktı. Özellikle Ege bağlantı limanının bulunması İstanbul'a gelen yük gemileri ve kalabalığı buraya çekecek, Rusya'nın Karadeniz'de kuracağı ticari gemi filolarını da engelleyecekti. Askerî açıdan ise bu hat Rumeli'nin önemli bölgelerini Çanakkale Boğazı ve İstanbul'a bağlayacaktı. Böylece Asya'dan gelen askeri birlikler yeni limana ulaştırılarak, buradan tren hattıyla hızlı ve kolay bir şekilde gerekli yerlere ihtiyaç anında sevk edilebilecekti (Engin, 1983, s. 44-45).

Rumeli Demiryollarının inşası için hazırlana 1869 tarihli imtiyaz sözleşmesinin 1.maddesinde hattın Karadeniz bağlantısı Varna yerine Burgaz (Bergos)'a, Ege bağlantısının da İnöz’e uzatılacağı belirtilmekle beraber, sözleşmeye ilişkin bazı kararlar hükümete bırakılmıştı. Bu kararlar arasında Edirne-İnöz demiryolu hattının yapımı için Meriç nehrinin ıslahı gerekli olduğundan hattın buraya yapılıp yapılmayacağına, devletçe yapılacak araştırma sonrası, mukavelenin tasdikinden bir yıl sonra karar verilmesi öngörülüyordu ${ }^{2}$. Rumeli Demiryolları ana hattının İnöz'e bağlantısı konusunda hükümetin tereddüdü, bu limanda yapılan incelemeler sonucunda şirketin de yer seçimi konusunda planlarını değiştirmesine neden olmuştur. Şirket, buraya inecek 149 kilometrelik hattın son noktasının İnöz'ün Güneybatısında bulunan Dedeağaç’a yapılmasını teklif etmiştir. Çünkü İnöz limanında

\footnotetext{
${ }^{2}$ Cochran, Rumeli Demiryollarının ilk projesinde Ege denizine açılacak bağlantı noktasının İstanbul'a yakın ve Türkler tarafindan kontrolü daha kolay olan Rodoscuk (Tekirdağ) limanının seçildiğini, ama Rusya'nın başka yollarla araya girerek Balkanlar'da etkisini artırmak için kendi lehine bu hattı sağlıksız ve hiçbir özelliği olmayan Dedeağaç'a yönlendirmeyi başardığını, ileride buradan Akdeniz'e rahatlıkla açılıp, Karadeniz ve Akdeniz'den İstanbul'a rahatlıkla saldırabileceği tespitinden bulunarak yer seçiminin stratejik olarak uygun olmadığını yazar ( Cochan, 1887, s. 323).
} 
yapılan keşiflerde, buraya dökülen Meriç suyunun limanın bazı bölgelerinde adalar oluştuğu ve deniz suyu derinliğinin de 1.5-2 metreyi geçmediği tespit edilmiştir. Buna karşılık Dedeağaç’ta su derinliğinin 3 metreye ulaştığı ve havasının da liman için elverişli olduğu tespit edildiğinden, Edirne'den Ege'ye uzanacak hattın son noktasının Dedeağaç’a yapılması 1870’te kararlaştırılmıştır (Engin, 1983, s. 59, 65; Temirtsidi, 2009, s. 38; Cochran, 1887, s. $322)$.

Aslında İnöz’ün ilk demiryolu planında son nokta olarak tercih edilmesi buranın tarih boyunca bölgenin önemli bir limanı olarak hizmet etmesinden kaynaklanmaktadır. Meriç nehri üzerinden başta Edirne olmak üzere bölgenin tarımsal ürünleri İnöz’e taşınıyor ve buradan diğer bölge veya Avrupa'ya ihraç ediliyor ve benzer şekilde de aynı yoldan Edirne'ye ithal ediliyordu. Ayrıca İnöz limanı Osmanlı başkenti İstanbul'un iaşesinde de çok önemli bir role sahipti. Ancak limanı yüzyıllar boyunca Meriç suyunun taşıdığı kum ve çamurlar yüzünden dolmuş ve büyük gemilerin demirlemesine veya yüklerini boşaltmasına uygun özelliğini kaybetmişti. Özellikle 1840'lardan itibaren yük ve yolcu taşımacıllığını üstlenen buharlı gemiler için limanı uygun değildi. Bu nedenle İnöz limanı 18. yüzyıldan itibaren önemini kaybetmeye başlamış ve yerini Rodoscuk (Tekirdağ) limanına kaptırmıştı (Aydin, 2020, s. 22-23).

\section{Edirne-Dedeağaç Demiryolu ve Bir Liman Kentinin Doğuşu}

Dönemin Osmanlı hükümetinin 1870 yılında Edirne-Ege sahili bağlantısının son noktası olarak İnöz yerine Dedeağaç'ı seçmesi ve hattın 1872 yılında tamamlanması bölgenin tarihini derinden etkilemiştir. Daha önce üzerinde hiçbir yerleşim birimi ve limanı bulunmayan ve hiç tanınmayan, etrafı bataklıkla çevrili, kurak bir yer olan Dedeağaç, demiryolu hattı sayesinde kısa sürede önemli bir liman kentine dönüşür. Yakın çevresinde bulunan İnöz, Ferecik ve Mekri gibi kadim yerleşim birimlerinin demografik ve ekonomik açıdan gerilmesine neden olur (Kiel, 1995, s. 371-373).

Daha önceleri bir yerleşim birimi olmayan Dedeağaç’ın Rumeli Demiryollarının Ege Denizi'ne bağlantı noktası olarak seçilmesinden önceki dönemine ilişkin çok fazla bir bilgi mevcut değildir. Dedeağaç'ın bir kasabaya dönüşmesinden sonra, kente ilişkin verilen bilgilere göre, Dedeağaç'1n $12 \mathrm{~km}$ kuzeyinde antik Egnatia yolunun üzerindeki tepelerde Trayanapolis olarak anılan antik kentin harabeleri bulunmaktadır. Bu kent antik dönemde oldukça önemli bir kentti ve limanı da bu dönemde Ege adalarıyla gerçekleştirilen ticarette önemli rol oynamaktaydı. Son derece mamur olan kent barbar akınları sonrası tahrip olarak bir harabeye dönüşmüştür (Salname, 1310, s. 559; Ahmet Badi, 2014, s. 2199-2202). 
Dedeağaç, Rumeli demiryolları Kuleli Burgaz'dan buraya hattı inşa edene kadar yerleşimi bulunmayan meşe ağalarıyla dolu, önemsiz ve boş bir araziydi (Şemseddin Sami, 1308, s. 2123; Tozer, 1890, s. 313; Temirtsidi, 2009, s. 23-24).

Geleneksel anlatılara göre, bölgenin Dedeağaç veya Dedeağacı adını burada bulunan bir Bektaşi tekkesinde asırlık bir meşe ağacının gölgesinde oturmayı adet edinen bir Bektaşi babasından aldığı söylenir. Bazı Türk araştırmacılar demiryolu açılana kadar burasının küçük bir balıkçı köyü olduğunu da iddia ederler. 1668 yılında bölgeyi ziyaret eden Evliya Çelebi Dedeağaç'ın 12 km kuzeyindeki antik Trayanopolis harabeleri yakınında bulunan Nefes Dede tekkesini ziyareti sırasında, Nefes Baba'nın mezarının orada bulunduğunu yazar. Ayrıca 1715 yılında Mora seferi sirasında Sultan III. Ahmet de tekkeyi ve Nefes Baba türbesini ziyaret eder. Bu bölgede Nefes Baba ve tekkesinin mevcut olduğuna dair bu bilgiler Dedeağaç adının Nefes Baba'dan gelmiş olabileceğine dair iddiaları destekler niteliktedir (Evliya Çelebi, 2003, s. 33-34; Tuğlacı, 1985, s. 338; Ahmet Badi, 2014, s. 2199-2200; İlhan, 2016, s. 32-33). Çağdaş Yunanca kaynaklarda da bu anlatıyı destekleyici bilgiler verilmektedir. Bu kaynaklara göre, burada bulunan asırlık bir meşe ağacının altında bir dervişin mezarı bulunuyordu ve bu nedenle burası Dedeağaç olarak anılıyordu. Bir başka anlatıya göre de buradaki sahile gölge sağlayan çok yaşlı meşe ağaçları bulunuyordu ve bu nedenle de Dedeağaç olarak adlandırılıyordu. Sonuçta bu mevkiinin adının Bektaşi Nefes Babaya atfen böyle adlandırıldığını söylemek yanlış olmasa gerek (Sarpidon, 1897, s. 310-311; Bakirtzis, 2019, s. 17; Temirtsidi, 2009, s. 29-30).

Dedeağaç'ın İnöz yerine liman bağlantısı noktası olarak seçilmesinin en önemli nedeni bulunduğu yerin istasyon, depo ve çalışanların kalabilecekleri baraka ve binaların inşası için oldukça uygun olması yanında, bölgenin bir vakıf arazi olması ve demiryolu hattının çok fazla köprü ve menfez gerektirmeden görece daha kolay inşa edilebileceği bir yer olmasından kaynaklanıyordu. Nitekim Osmanlı devleti Dedeağaç’ta yapılacak istasyon ve binaların yapımı için gerekli araziyi buradaki Sultan Beyazıt vakfı arazisinden şirkete tahsis etmiştir (BOA.Y.MTV.326/6, H.1288/M.1872; BOA.DH.MKT. 1791/2, H.1306/M.1890). ${ }^{3}$ Ayrica denizinin büyük gemilerin demirlemesi veya yük boşaltması için uygun derinlikte olması da buranın tercihinde önemli bir rol oynamıştır. Dolayısıyla İnöz yerine Dedeağaç'ın şirket tarafından tercih edilmesi, bölgenin sağladığı ekonomik avantajlardır. Devlet şirkete Beyazıt

\footnotetext{
3 Evkaf Nezaretine 1890 yılında gönderilen bir arzda Rumeli Demiryolları şirketine ait tren istasyonu dahil olmak üzere burada bulunan şirkete ait bütün binalar ile başkalarına ait bütün han, hane, dükkan, mağazaların arazi üzerinden yeterince gelir elde ettikleri belirtilerek vakıf şartına binaen söz konusu vakfa zemin kirası ödemeleri talep edilmektedir (BOA.DH. MKT. 1791/2, H.1306/M.1890).
} 
vakfına ait olan bu arazilerini kolaylıkla tahsis edebilecekti ve bir kamulaştırma bedelinin ödenmesine de gerek kalmayacaktı (Alepakos, 2017). 1872'de demiryolu ve istasyonun işletmeye açılmasına rağmen, uzun süre buraya inşa edilmesi planlanan limanın yapılmaması ve dalga kıranların bulunmaması, Dedeağaç limanını uygun derinliğine rağmen yük ve yolcu gemileri için denizde lodos estiği dönemlerde oldukça tehlikeli bir hale getirmiştir (Sarpidon, 1897, s. 312-314).

Dönemin İstanbul gazetelerinde ${ }^{4}$ yer alan haberler göre, Edirne-Dedeağaç demiryolu hattının inşaatı 1871 yılı başlarından hattın iki ucundan aynı zamanda başlatıldı. Tren istasyonu ile şirketin binaları, depoları ve ilk liman projesi mimar Guerard ve Dussaud tarafindan hazirland1 $\quad$ (BOA.PLK.P.4238,1873;

BOA.PLK.P.5083,1872; BOA.Y.PRK.TNF.2/7,1887). 1871 Haziranında demiryolu inşası için gerekli raylar, ray demirleri, vagonlar, lokomotif ve diğer malzemeler 6 gemiyle Dedeağaç önlerine getirildi. Getirilen bu malzemeler peyderpey Dedeağaç’a boşaltılıyordu. Lodos nedeniyle gemilerden bazıları batma tehlikesi yaşayınca yüklerini denize atmak zorunda kaldılar. $\mathrm{Bu}$ arada gelen malzemelerin lokomotiflerle hattın inşa edildiği bölgeye taşınmaları için Meriç nehrinin üzerinde 45 metrelik bir ahşap köprü de inşa edilmişti. İstasyon inşaatı da hızlı bir şekilde ilerliyordu. Bu arada Mekri ve İnöz'den çok sayıda tüccar buraya yerleşmeye başlamıştı. 1871 Kasımında gemiler hala yüklerini boşaltmaya devam ediyordu. Dedeağaç-Ferecik hattı işlemeye başlamıştı, ayrıca istasyon inşaatıyla beraber depoların yapımı da devam ediyordu. Demiryolu inşaatı sorunsuz bir şekilde ilerlerken, kış aylarında bölgeye yoğun yağış düşmesi önemli problemlere ve buna bağlı kazalara neden oldu. Meriç nehrinde yaşanan taşkınlıklar nedeniyle bazı köprü ve menfezlerin yıkılması demiryolu inşaatı ve bağlantısında önemli aksamalara neden oldu. Yaşanan bu sorunlara rağmen demiryolu inşaatı 1872 yılı Ekim'inde tamamlanarak 50 vagondan oluşan deneme seferi yapıldı (BOA.MKT.MHM.449/4, 26 Şubat 1873; BOA.MKT.MHM.449/14, 26 Şubat 1873; Alepakos, 2017). ${ }^{5}$

Demiryolu inşaatının tamamlanması ve Dedeağaç tren istasyonun açılmasıyla beraber, hattın inşası için buraya gelen şirket yöneticileri, mühendisleri, teknisyenleri ve işçileriyle beraber limana yakın bölgede yeni yerleşim konutları ve depolar şirket tarafından inşa

\footnotetext{
${ }^{4}$ İstanbul'da Rumca yayınlanan Neologos ve Anatolikos Astir gazetelerinden (akt. Alepakos, http://alepakos.blogspot.com/2017/10/dede-aghadj.html)

51 Şubat 1873 tarihinde saat 6'dan 12'ye kadar durmadan yağan yağmur Meriç nehri ile Sekbanl1, Ilıca ve Podem çaylarının taşmasına neden olup bu çayların üzerinde olan demiryolu köprülerinin tamamına yakınını yıkarak buradan geçen hatların toprak ve ağaç yığınları altında kalmasına ve hattın bazı yerlerde yıkılmasına neden olmuştur. 9 Şubat'ta demiryolu komiseri Milosoviç hasarı tespit için hat boyunca keşifte bulunarak durumu tespit etmiş Dedeağaç ile Edirne arasındaki seferler durdurulmuş ve acilen bozulan yerlerin tamiri işlemine başlanmıştır. Detaylı bilgi için bk. (BOA.MKT.MHM.449/4, 26 Şubat 1873; BOA.MKT.MHM.449/14, 26 Şubat 1873).
} 
edilmiş, böylece Dedeağaç'ta ilk yerleşim oluşmuştu. Şirket çalışanları ile resmi görevliler dışında Dedeağaç'a ilk yerleşenler, çalışmak veya iş kurmak için İnöz, Mekri, Maronia ve Edirne gibi yakın kasabalardan gelen Rumlardı. Buraya gelen ve yerleşen Rumlar denizcilik, işçilik ve ticaret işleriyle uğraşıyorlardı. Yeni yerleşim birimindeki Müslümanlar ise devlet memurları ve aileleriydi. Ayrıca demiryolu şirketindeki görev yapan Ermeni ve Yahudiler ile bazı Avrupalılar da yerleşmişti (Hüseyin Pertev, 1313, No: 71; Temirtsidi, 2009, s. 41-43, 72; Vasilopoulos, 1914, s. 58).

Edirne-Dedeağaç demiryolu hattının inşası sırasında, istasyon, depo, atölye ve karantina binalarının yapımı sürerken bir liman yapılması için hükümet ve demiryolu şirketi tarafından mühendis Tafarel görevlendirilerek Dedeağaç’ta bazı çalışmalar yapıldı, ancak uzun süre liman yapımı gerçekleştirilemedi. Rumeli Demiryolları şirketi ile yapılan anlaşmaya göre Osmanlı devleti demiryolları ile bağlantı hatları kurulacak Selanik, Dedeağaç ve Varna limanlarının inşasını garanti ediyor ve 10 milyon Franklık bir bütçe ayırmayı da vadediyordu. Ancak bunu gerçekleştiremeyen Osmanlı hükümeti, başlangıçta Dedeağaç’ta bir kayık iskelesi inşa edilmesi ve şamandıralar konulması için yaklaşık şirkete 400 bin Frank vermeyi kabul etti (Mehmet Cavit, 1324, s. 88, 101). İnşa edilen kayık limanı ve ahşap bir rıhtım üzerinden liman ciddi zorluklara rağmen, ticari faaliyetler başlayıp 20. yüzyılın başlarında yeni liman inşa edilinceye kadar faaliyetlerine devam etti. Limanda artan gemi trafiği nedeniyle 1880 yılında sahile hükümet tarafından ticari ve balıkçı gemilerine yardımcı olmak için bir deniz feneri de inşa edilerek, korunaklı bir limanı olmayan yeni kasabaya gemilerin güvenle yaklaşması için önemli bir adım atıldı (Temirtsidi, 2009, s. 52-53, 57).

Rumeli Demiryolları şirketi tarafından yeni kurulan Dedeağaç, Edirne ve İstanbul ile demiryolu bağlantısı olan bir liman kasabası için bulunması zorunlu genel amaçlı binalar, karantina binası, demiryolu ve liman işletmesinde çalışanların ihtiyaçlarını karşılamaya yönelik ev ve mağazalarla canlı küçük bir kasabaya dönüşmüş; sunduğu iş, ticaret ve ulaşım imkanlarıyla art bölgesinde yer alan kasabalar ile adalardan nüfus çekmeye başlamıştı. Böylece liman ve istasyon bölgesi kasabanın idari ve ticari merkezi haline geldi. Kasaba bu merkezden gelişmeye ve biçimlenmeye başladı. Dedeağaç'ın Trakya ve Rumeli'nin tarımsal ve ticari ürünlerinin çıkış ve Avrupa sanayi ürünlerinin giriş merkezine dönüşmesi, kasabanın bir taraftan demografik ve ekonomik açıdan büyümesine neden olurken, diğer yandan art alanında bulunan Mekri, Ferecik, İnöz gibi kadim yerleşim birimleri nüfus ve ekonomik canlılığını kaybetmeye başladı. Ayrıca bölgede İstanbul ve Edirne gibi kentlerin iaşe ve ticari ihtiyaçlarını karşılayan ekonomik açıdan oldukça önemli bir rol oynayan Rodoscuk 
(Tekirdağ) limanının ve kentinin önemini yitirmesine ve gerilemesine de neden olmuştur. Demiryolu bağlantılı yeni kurulan Dedeağaç limanının yakın gelecekte bölge üzerindeki etkisinin farkında olan ve Edirne'nin Ege'ye açllan limanı görevini uzun süredir sürdüren İnöz sakinleri Osmanlı hükümeti nezdinde demiryolu bağlantı hattının Dedeağaç yerine İnöz’e bağlanması için uzun süre mücadele etmişlerse de bir sonuç alamamışlardır. Sonuçta Rumeli Demiryolları ekonomik açıdan oldukça uygun olan Dedeağaç'ı tercih etmiştir (BOA. ŞD. 190/52, H.1288/M. 1871; BOA. ŞD. 2883/12, H. 1292/M. 1875). ${ }^{6}$

Dedeağaç kasabasının kuruluşundan kısa bir süre sonra 1875 yılında idari bakımdan Ferecik kazasına bağlı bir nahiye merkezine dönüşerek idari bakımdan da önem kazanmaya başladı. Nahiye olduğu için bir müdür tarafından idare ediliyordu ve ayrıca bir liman kasabası olduğu için belediye idaresi de kurulmuştu. Belediye, başkan ve üç meclis üyesinden oluşuyordu. Kasabada güvenlik için ayrıca bir askeri birlik de bulunuyordu. Kasabanın kuruluşundan sonra basılan 1291/1874 tarihli Edirne Vilayeti salnamesinde Dedeağaç idari bir birim olarak yer almazken, yeni yerleşim yerinden sadece demiryolu hattı bağlantısı nedeniyle bahsedilmektedir. 1293/1876 tarihli salnamede nahiye olarak anılırken, limanı da Ferecik limanı olarak adlandırılmakta ve buraya uğrayan gemi sayısı da 9 adet olarak verilmektedir. $\mathrm{Bu}$ tarihten itibaren Lyod ve Frassitine vapur şirketleri bu limanı düzenli olarak ziyaret etmeye başlamışlardı. Bu tarihte Dedeağaç'ın kayık limanı ile yükleme ve boşaltma rıhtımı henüz yapılmadığı ve basit bir iskele olduğu için İnöz limanı daha aktif kullanılıyordu (Salname, 1291, s. 132; Salname, 1293, s. 98, 148; Ali Saib, 1304, s. 62). Dedeağaç' in nüfus ve ticari faaliyetlerinin giderek artması Osmanlı idarecilerinin kasabanın statüsüyle ilgili yeni düzenlemeler yapmasına neden olmuş ve böylelikle 1876 'da nahiye statüsünden idari birim olarak Dimetoka Sancağına bağlı yeni bir kaza ve kaza merkezine dönüştürülmüştür. (BOA.ŞD.2885/30/1, H. 1291/M.1876; Ali Saib, 1304, s. 49; Annuaire, 1883, s. 555; Annuaire, 1881, s. 465). Kasabanın kaza merkezine dönüşmesiyle birlikte kısa sürede kaza örgütlenmesi için gerekli idari, adli ve askeri birimler kurulmuştur. Dedeağaç'ın kaza teşkilatıyla ilgili detaylı bilgiler 1301/1883 tarihli Edirne Vilayet salnamesinde de yer almaktadır. Salnamedeki bilgilere göre kaymakam, kaymakamlığa bağlı idari birimlerle, kaza idare meclisi, ticaret ve ziraat odaları da kurulmuştu. Ticaret odasının tamamı Rumlardan oluşurken, ziraat odasının 4 üyesinden sadece biri Müslümandı. Belediye başkanlığını Andon

\footnotetext{
${ }^{6}$ İnöz kasabasının Müslim ve Gayrimüslim sakinleri Edirne Vilayet Meclisi'ne demir yolu hattının önceden planladığı gibi bu kasabaya bağlanmasını, Dedeağaç limanının uygun bir yer olmadığını ve aksi takdirde zahire ve ticaret bakımından kasabanın kısa sürede bir harabeye dönüşeceğini öne sürerek planda bir değişiklik yapılmamasını talep etse de, Vilayet Meclisi şirket mühendislerinin ve devlet görevlilerinin uzun süre bölgede inceleme yaptıktan sonra Dedeağaç’ta karar kıldıklarını belirterek, halkın talebini reddetmiştir. 1875 Dedeağaç’a kayık limanının inşasına da İnözlüler benzer şekilde itiraz etmişlerdir.
} 
Efendi ile 4 üyenin tamamını Rumlar temsil ediyordu. Kasaba nüfusu 1883'te 3.000'e ulaşmış ve nüfusunun büyük çoğunluğunu Rumlar oluşturuyordu. Bu nedenle idari, adli ve beledi birimlerde Rum cemaati temsilcileri aktif görevler alıyorlard1. Kasabadaki ticari faaliyetler Rum tüccarların kontrollünde olduğu için doğal olarak yabancı devlet konsolos vekillikleriyle vapur şirketleri temsilcilikleri de Rumların tekelindeydi. Ayrıca kazada İslam ve Rum Cemaat meclisleri de bulunuyordu ${ }^{7}$. Müslümanların yaşadığ 1 Muslihiddin mahallesinde 1877 yılında ilk cami ahşap olarak inşa edilmiştir. Ayrıca kentte Fransız, İngiliz, Yunanistan, Avusturya, İtalya ve İran konsolos vekilleri ile Lyod, Mesajik, Fraissinet ve İzmir Babil (Bell) vapur acentalarının temsilcilikleri bulunuyordu. Dedeağaç kazasına, köy statüsüne düşürülen Ferecik dahil 40 köy bağlıydı (Salname, 1301, s. 185-188; Ahmet Badi, 2014, s. 2199-2202).

1877/78 Osmanl1-Rus savaşı hem Trakya bölgesinin hem de yeni gelişmeye başlayan Dedeağaç'ın Ruslar tarafından işgal edilmesi bir süre gelişimini kesintiye uğratmıştır. 6 Şubat 1878'te 750 kişilik bir Rus birliği Osmanlı ordusunca boşaltılmış olan kasabaya girerek karantina binası dışında bütün resmi binalar ile erzak ve mühimmat depolarına el koyup, gemilerin limana giriş ve çıkışını yasakladı. Bir idare heyeti kurarak kasabayı idare etmeye başladılar. İdare heyetinin başına da bir Rum getirildi (BOA.HR.SYS.1341/76, H.1295/M.1880; Alepakos, 2018). Dedeağaç limanı, kurulmasını planlanan Bulgar devleti ve Rusya için Akdeniz’e açılan önemli bir stratejik liman olacaktı. Rus askeri işgali sırasında kasaba ve bölgeden bulunan Müslümanların önemli bir kısmı buraları terk ederken, yerlerine Bulgar nüfus yerleşmiştir (Temirtsidi, 2009, s. 85-88). Berlin Anlaşması nedeniyle 1879 yılı Şubat ayında kasaba ve bölgeden çekilen Rus ordusu demiryolları ve tesislerine büyük zarar vermiş, bazı hatlardaki ray demirlerini ve malzemeleri alarak beraberlerinde Şarki Rumeli’ye götürmüşlerdi. ${ }^{8}$ Bu hasarın tazmini için de Osmanlı hükümeti şirkete 2 milyon Frank ödemeyi

\footnotetext{
7 Bu cemaat meclisleri büyük olasılıkla Rumeli vilayetlerinde 1878 Berlin Anlaşmasından sonra Rumeli'de öngörülen reformlar nedeniyle kurulmaya başlanmıştı. Bu nedenle bu tarihten sonra salnamelerde nahiye dahil yerleşim birimlerinde nüfusa göre İslam, Rum, Yahudi ve Bulgar cemaat meclisleri bulunuyordu. Edirne Vilayetinde Gayrimüslim cemaat meclisleriyle beraber neden İslam cemaat meclislerinin de kurulduğu ve meclislerin işlev ve yetkileri ayrıca araştırılması gereken bir konudur. Konuyla ilgili kısmi bilgiler için bk. (Furat, 2013, s. 73-77; Karal, 200, s. 77).

${ }^{8}$ Osmanlı hükümetinin Rumeli Demiryolları şirketi yetkilerinden aldıkları bilgilere göre Ruslar Rumeli işgal ettiklerinde işgal bölgelerindeki şirkete ait 1.130 vagon ile 56 lokomotif ellerine geçmişti. Ruslar vagonları, lokomotif ve hatları kullanmak için şirket ile gizli bir sözleşme imzalamıştı, ancak şirketin sahibi Baron Hirsch sözleşmeyi kabul etmemiş ve Rusların ellerinde bulan vagon ve lokomotifleri İstanbul'a getirmeyi planlıyordu. Rusya planları gerçekleşmeyince, hatları kendi imkanlarıyla asker ve malzeme naklinde kullandı. Berlin Anlaşması gereği, geri çekilirken Dedeağaç'ta depolarda Pleve-Sofya hattı için tutulan 50 millik ray demirleri ve çubukları beraberinde götürmüş ve Şarki Rumeli'de satışa çıkarmıştı. Bunu öğrenen Osmanlı devleti bu ray demirlerini talep etmiş, ancak Rusya bunları savaş ganimeti olduğunu ve mütarekeden önce oraya götürüldüğü iddia ederek iadeye yanaşmamıştı. Bu konu iki devlet arasında müzakere konusu olarak bir süre daha devam etmiştir. Ayrıntılı bilgi için bk. (BOA. HR.SYS. 232/12, 1879; BOA.Y.PRK.AZJ. 2/31, H.1295/M.1878).
} 
taahhüt etmiştir (BOA. HR.SYS. 232/12, 1879; BOA.Y.PRK.AZJ. 2/31, H.1295/M.1878; Mehmet Cavid, 1324, s. 104).

Rusların bölgeden çekilmesiyle beraber, Dedeağaç yeniden işlek bir limana dönüşmeye ve eski canlılı̆̆ını kazanmaya başlar. Kasabanın işgalden dört yıl sonra, 1883 yılında, nüfusu artarak 3.000 kişiye ulaşır. Rumeli'nin Ruslar tarafından işgali sonrası bölgenin ve özellikle de Dedeağaç'ın Osmanlı devleti açısından stratejik önemi daha da artar. Rumeli’ye demiryolu ile bağlantısı olan bu liman kenti, ileride Balkan devletleri ve Rusya saldırılarına karşı ve bölgede çıkması muhtemelen isyanları önlemek için Osmanlı ordusunun bölgeye asker ve cephane sevkinde önemli bir lojistik merkezi olarak görülür. İleride, Selanik-İstanbul arasına yapılması tasarlanan demiryolu hattı burayı daha da önemli bir hale getiriyordu. $\mathrm{Bu}$ nedenle Dedeağaç kazasının bir an önce sancak ve sancak merkezine dönüştürülmesi için çalışmalar başlatıldı. 1884 tarihli Tâksimât-1 Vilâyât Komisyonu'nun önerisiyle ve padişahın onayıyla Dedeağaç sancak ve sancak merkezi statüsüne yükseltildi. Bu kararla Dedeağaç hem sancak hem de aynı adla kaza merkezi olur. Dedeağaç sancak sınırları, Saltık, Karaca Halil, Kuleli Burgaz ve Karakilise nahiyeleri doğrudan sancağa bağlı olacak şekilde, Sofulu ve Ortaköy kazalarını içerecek şekilde belirlenir (BOA. İŞD. 69/4091, H.1300/M.1884; Salname, 1302, s. 177-255). Dedeağaç'ın sancağa dönüştürülmesi üzerine 1877 vilayet nizamnamesine uygun olarak bir mutasarrıf ile mutasarrıflığa bağlı kalemler ve liva meclisi oluşturulur. İlk mutasarrıf olarak İşsodralı ve Rum milletine mensup Arnavut kökenli Corci (Georgi/Jorji) Paşa atanır. ${ }^{9}$ Padişahın iradesiyle Dimetoka birinci sınıf kazaya, Dedeağaç da sancağa dönüştürülünce, Dimetoka mutasarrıfı Corci Paşa ${ }^{10}$ Dedeağaç'a yeni mutasarrıf olarak atanmıştır (BOA. SAİD.d. 4/398, H.1309/1891; Annuaire, 1885/1886, s. 420; Salname, 1302, s. 177; Bakirtzis, 2019, s. 21).

Dimetoka'dan Dedeağaç'a taşınan sancak merkezinde, muhasebe, tahrirat, mahkeme-i şeriye, mahkeme-i bidayet, aşar idaresi, defter-i hakani, evkaf idaresi gibi mutasarrıflık idari birimleri ile liva meclisi, istintak dairesi ve sancak askeri idaresi gibi birimler de hizla kasabada yerini almıştır. Sancak idari birimleri için henüz yeterli binaların olmadığı kasabada

\footnotetext{
9 Sicil-i Ahvâl kaydına göre, Corci Paşa İşkodra hanedanından Petro Petroviç'in oğludur. 1843 tarihinde İşkodra'da doğmuştur. Ana dili Arnavutça olup, Türkçe, Fransızca, İtalyanca ve Rumcayı iyi derecede bilir. 1863 yılında saray muhafız alayına (silahşorân) alınmış, 1870 yılında Manastır sancağı mutasarrıf muavinliğine atanarak ilk idari kariyerine başlamıştır. Ardın sırasıyla Girit Kandiye sancağı muavinliği, 1877'de Girit vilayeti müşavirliği, 1879 'da Dimetoka ve 1884 'te Dedeağaç mutasarrıflığına atanmıştır. 1886'da Dedeağaç'taki görevinden azledilmiştir. Ayrıntılı bilgi için bk. (BOA. SAİD.d. 4/398, H.1309/1891).

${ }^{10}$ Corci Paşa 9 Şubat 1879 tarihinde Edirne'den gelen Osmanlı kuvvetlerinde başında Dimetoka'ya gelerek burasını ve sancağı Rus kuvvetlerinden teslim almıştır. Dimetoka'ya gelişi sırasında kentin Rum metropoliti ve büyük bir kalabalık tarafından büyük bir törenle karşılanmıştır. Ardından da Dimetoka sancağı mutasarrıfı olarak görevine başlamıştır. Detaylı bilgi için bk. (Bakirtzis, 2019, s. 21, dipnot 2).
} 
sancak idaresi yer bulmakta zorlanıyordu. Bu yeni idari taksimattan bir yıl önce, Ferecik gibi, bölgenin eski ve iskelesi olan Mekri de Dedeağaç'ın bir nahiyesine dönüştürülmüştür. (Salname, 1301, s. 189-190). 1884 yılı sancak verilerine göre, Dedeağaç kazası nüfusu 19.831'e ve sancak nüfusu da 51.817 kişiye ulaşmıştı. Dedeağaç mutasarrıfı Corci Paşa'nın Rum milletine mesup olması, kasabanın nüfusunun önemli bir kısmının Yunan ve Rum olması, Yunan meselesinin de ortaya çıktığı bir dönemde bu memuriyete bulunmasının uygun olmayacağı değerlendirilerek Babıali tarafından görevinden alınmıştır (BOA.DH.MKT.1429/83, 5 Temmuz 1887). ${ }^{11}$ Yerine Yusuf Bahaddin Bey atanmıştır. 1887 tarihli salnameden anlaşıldığı kadarıyla Dedeağaç sancağı idari sınırlarında da bir düzenleme yapılarak sancak, Dedeağaç, Sofulu ve İnöz kazaları, Ferecik, Mekri, Şahinler ve Doğanhisar nahiyeleri ile çok sayıda köyden oluşan nihai sınırlarına ulaşmıştı. Ardından, Semadirek (Samothraki) adası da nahiye olarak Dedeağaç'a bağlanmıştır. Yeni liman kentinin belediye idaresi de bu dönemde, kasabada çoğunlukta bulunan Rum belediye başkanı ve üyelerden oluşuyordu ve uzun süre de böyle devam etmiştir (Salname, 1305, s. 190-197; Salname, 1306, s. 193).

Dedeağaç sancak merkezine dönüştürüldükten sonra kısa sürede hızla gelişmeye ve Avrupa tarzında bir liman kentine dönüşmeye başlaması dönemin İstanbul Rum gazetelerinden Neologos'ta övgüyle anlatılmaktır. Gazeteye göre, Dedeağaç'ın ilk kurulduğu yıllardaki halinden bir eser kalmamış, tersine Avrupai bir kente dönüşmüştür. Sürekli buharlı gemliler iskeleyi ziyaret etmekte ${ }^{12}$, buraya demiryoluyla getirilip depolanan tahılları alıp başka limanlara taşımaktalar, kentte sigorta şirketleri, yabancı devletlerin konsolos vekilleri yerleşmiştir. Kentte taş binalar, oteller, iş yerleri kahvehaneler inşa edilmiş ve yenileri de inşa edilmektedir. Avrupa tarzda geniş ve düz yollar yapılmış, belediye kente içilebilir su getirmek

11 Berlin Anlaşması'nda Rumeli ve Makedonya'da Hıristiyan Osmanlı tebaası için reform yapılması kararlaştırıldığı bir dönemde Trakya'da yeni kurulan sancağa Osmanlı yöneticilerinin Avrupa devletleri ve kamuoyunda olumlu bir imaj oluşturmak için Corci Paşa'yı ataması ve ardından siyasal konjonktüre uygun bir şekilde Girit meselesi ve Yunanistan'ın Tesalya bölgesinde hak iddiasında bulunduğu bir dönemde görev alınması bu dönemde sık görülen bir uygulamaydı. Görevden alındıktan sonra Corci Paşa kendisine tahsis edilen maaşla geçim zorluğu yaşadığını beyan ederek, benzer bir göreve atanmasını talep etse de Osmanlı yönetimin bu talebini uygun bulmamıştır. Ancak sonraki yıllarda yine kendisine Girit ve Rumeli'de yeniden önemli görevler vermiştir. Corci Paşa'nın Osmanlı devletindeki kariyeri ve aldığı görevlerle ilgili olarak bk. (BOA. SAİD.d. 4/398, H.1309/1891).

12 İngiliz William Cochran 1887 tarihli eserinde Dedeağaç limanını küçük bir liman olduğunu ve küçük tekneler tarafından kullanıldığını, büyük vapurların demirlemesi ve yük alımı için uygun derinliğinin olmadığını ve bu nedenle gemilerin açıkta demirlediklerini ve lodos estiği zaman bu gemilerin büyük tehlike atlattıklarını belirterek, uygun limanın yapılması durumunda Avrupa için elzem olana tarımsal ürünlerin ihracatının artacağı ve kentin çok değer kazanacağını belirtir. Yük gemilerinin Çanakkale ve İstanbul Boğazlarında ödedikleri gümrük vergilerinden ve taşıma risklerinden kaçmak için bu limana rağbet göstereceklerini vurgular. Dedeağaç'ın bir kasaba olarak ziyaretçilere çekecek bir özelliği olmadığını da yazar. Yeni kurulmuş bir kent olduğu için klasik bir Akdeniz liman kentinin tarihsel yapılarından eser yoktur ve bu nedenle Semadirek Adası'na gitmeyi tercih eder (Cochran, 1887, s. 320, 323). 
için çalışmalar yapmakta, liman ve sahiller sürekli temizlenen modern bir kenttir. (Neologos, 30 Ağustos 1884, No: 4590; Bakitzis, 2019, s. 29, 49; Annuaire, 1885/86, s. 420; Cochran, 1887, s. 320-324). Bu bilgileri 1892 tarihli salnamedeki veriler de desteklemektedir. Kasabada Musluhiddin ve Hamidiye mahallerinde iki cami, iki hamam, jandarma karakolu, kazaları ve merkezle bağlı telgrafhane, duyun-i umumiye binası, tuz ve gazyağı deposu, 12 çeşme ve büyüklü küçüklü 1.463 hane ve dükkan ile 5.000 civarında bir nüfus bulunuyordu. Bir Ermeni ve Rum kilisesi, iki Rum ve Müslüman ibtidaiye mektebi de mevcuttu. Ayrıca İnöz'de bulunan Rum Metropolitliği de buraya taşınmıştı. Karantina idaresi kayıtlarına göre 1890 yılında Dedeağaç İskelesini büyük bir çoğunluğu Yunan ve İngiliz olmak üzere 1.300 adet buharlı ve yelkenli gemi ziyaret etmişti. Dedeağaç limanı üzerinden İstanbul, İzmir, Selanik, Girit, İskenderiye, Pire, Trieste, Hamburg ve Anvers (Antwerp) limanlarına 6 şirketin düzenli seferleri bulunuyordu (Salname, 1310, s. 567-570; Gökbilgin, 1991, s. 200; Annuaire, 1889/90, s. 687; Sarpidon, 1897, s. 314) ${ }^{13}$. Bu veriler Dedeağaç'ın sancak merkezine dönüşmesinden yaklaşık on yıl içinde büyük bir gelişme göstererek bölgedeki en aktif liman kentlerinden birine dönüştügünü göstermektedir. Demiryolu hattı inşası sırasında Osmanlı devleti tarafından burada bir liman yapılacağına dair taahhüttün gerçekleşmemesi ve mevcut küçük limanın büyük buharlı gemilerin yanaşmasına uygun olmamasına rağmen, kısa sürede liman trafiği bir hayli artmıştır. Büyük gemiler yanaşması için uygun bir rıhtım olmadığından açıkta demirliyor ve yüklerini mavnalar veya kayıklara indirerek, rıhtıma taşıyor ve aynı yöntemle yüklerini alıyorlardı.

\section{Selanik-Dedeağaç Demiryolunun İnşası ve Dedeağaç'ta Dönüşüm}

Her ne kadar Dedeağaç 1872 yılında Rumeli Demiryolları şirketinin Edirne'den buraya bir bağlantı hattı kurmasıyla beraber kurulmuş, oldukça genç bir kent olsa da 1890 yılı öncesine ilişkin çok fazla kaynak mevcut değildir. Kentin tarihine ilişkin Türkçe kaynaklar yüzyılın sonunda artmaktadır. Özellikle 1896 yılında Dedeağaç-Selanik demiryolu bağlantısının hayat geçmesi, kentin daha fazla tanınmasına, dolayısıyla kent tarihiyle ilgili daha fazla malzeme üretilmesine neden olmuştur. Yine bu on yılda Dedeağaç'ta Osmanlı egemenliğini simgeleyen hükümet konağı, askeri kışla, hastane, hapishane, telgrafhane,

\footnotetext{
${ }^{13}$ Osmanlı İdare-i Mahsusası beş günde bir, Loyd, Fraissinet, Yunan Bell Asia Minor ve İngiliz Joly Victoria şirketleri haftada bir, Alman şirketi de ayda bir Dedeağaç'tan vapur seferleri düzenliyordu. (Salname 1310, s. 570). Kasabada çoğu Rumlar tarafından temsil edilen 11 yabancı sigorta şirketinin temsilcilikleri bulunuyordu. (Annuaire, 1889/90, s. 687). Bu vapurlardan birisiyle 1889 yılında Dedeağaç’1 ziyaret eden İngiliz Tozer, kasabanın yakın bir zamanda bölge ticaret için önemli bir üs olacağını vurgulayarak, henüz ulaşım imkanlarının sınırlı olduğunu ve çok hızlı gelişen kasabaların tipik özelliğini yansıttığını yazar. Bu ovadaki çiftçilerin Bulgar olduğunu boş arazilerde de Bulgar ve Ulah çitçilerin hayvanlarını otlattığını, kentin varoşlarında çok sayıda deve bulunduğunu, bunların demiryolu geçmeyen iç bölgelerden ticari ürünlerin istasyon ve limana taşınması için kullanıldığını anlatır (Tozer, 1890, s. 313).
} 
belediye, rüştiye ve idadiye gibi pek çok kamu binasının inşaatı tamamlanarak kente modern bir Osmanlı şehri görünümü kazandırmıştır (BOA.Y.MTV.133/15, 18 Aralık 1895).

Dedeağaç'ın kentsel dönüşümü ile askeri ve ekonomik açıdan önemini DedeağaçSelanik arasında yapılan yeni 510 kilometrelik demiryolu hattı, ilk demiryolu bağlantı hattında olduğu gibi, derinden etkilemiştir. Selanik-İstanbul iltisak hattı daha çok askeri gerekçelerle Doğu Rumeli'deki vilayetleri İstanbul ve Makedonya bölgesine bağlamak amacıyla tasarlanmıştır. Bu hat sayesinde İstanbul'dan ve Anadolu'dan Çanakkale üzerinden gelecek askeri birlikleri Selanik’e sevk etmek mümkün olacaktı. Dedeağaç-Edirne bağlantı yolu, Ferecik istasyonundan başlayıp Gümülcine, İskeçe, Drama, Serez, Demirhisar ve Doyran üzerinden Selanik'e ve oradan da başka bir hatla Manastır'a ulaşacaktı. Bu hattın imtiyazı 1892 yılında İstanbul'da bankerlik yapan Fransız Rene Baudouy'a 1.500 Frank kilometre garantisiyle verildi.1893 yılında başlayan demiryolu inşaatı 1896 yılında tamamlanarak işletmeye açıldı (Engin, 1993, s. 207).

Özellikle 1877/78 Osmanl1-Rus savaşları sırasında Doğu Rumeli ve Trakya'nın Ruslar tarafından işgal edilmesi Osmanlı yöneticilerini Dedeağaç bağlantılı İstanbul-Selanik demiryoluyla ilgili çalışmalara yönlendirmişti. Berlin Anlaşması sonrası Balkanlarda ortaya çıkan yeni statüko, Yunanistan, Karadağ, Sırbistan, Romanya devletleri ile Bulgar Prensliğinin Avrupa'da elde kalan Teselya, Makedonya, Trakya ve Doğu Rumeli gibi Osmanlı toprakları için artık ciddi bir tehdit oluşturuyordu. 1885'te üçe bölünen Bulgaristan topraklarının birleşmesi ve bunun Büyük Devletlerce tanınması Osmanlıları telaşlandırmış ve bu nedenle bir an önce gerekli askeri tedbirleri alarak bölgede gücünü artırmaya çalışmıştır (Jelavich, 2009, s. 391, 400-401).

Osmanlı genelkurmayı ile Nafia Nezareti bu hatla ilgili bir çalışma gerçekleştirerek, sonucu bir raporla Sultan II. Abdülhamit'e sunmuştur. Raporda Doğu Rumeli vilayetinin güneyi Rodop dağları ile kaplı olduğu için İstanbul'dan Batı Rumeli'ye ulaşım ancak denizyolu ile mümkün olduğundan, acil durumlarda bölgeye askeri kuvvet nakli sadece demiryolu ile mümkün olabilecekti. Bulgaristan, Avusturya, Karadağ ve Yunanistan sınırında bulunan ordunun başkentle bağlantısı ve ihtiyaçlarının zamanında temini için sahilden donanma tehdidinden uzak, en az $15 \mathrm{~km}$ derinlikte ve dağ silsilesine uygun bir şekilde bir demiryolunun acilen yapılması ve bu iltisak hattının Dedeağaç-Edirne hattına Dimetoka, Ferecik veya Dedeağaç üzerinden bağlanması önerilmiş ve sonuçta bağlantı güvenlik gerekçesiyle Ferecik üzerinde gerçekleşmiştir. Ayrıca aynı gerekçelerle, Dedeağaç limanının buraya akan dereler nedeniyle dolmaya başladığı belirtilerek bir an önce temizlenmesi için de 
Aydın, H. V. (2021). Rumeli demiryolları Ege Denizi bağlantı hattında yeni bir liman kenti: Dedeağaç (1872-1912). Humanitas, 9(17), 76-100

çalışmalar yapılması isteniyordu (BOA.Y.PRK.TNF. 24/49, 14 Haziran 1889; BOA.DH.1229/96204, 21 Mayıs 1891; DH.MKT.1676/69, 24 Kasim 1889). Makedonya bölgesiyle ilgili İngiliz deniz kuvvetleri istihbarat bilgileri de bu hattın askeri amaçlar nedeniyle özellikle denizden gelebilecek saldırılara karşı en az 15 km içeride yapıldığını ve bazı istasyonlarda askeri istasyon ile kışla inşa edildiği bilgisini vererek, Osmanlı devletinin planlarını doğruluyor. Nitekim bu amaçla Dedeağaç istasyonunun Güneydoğusunda 300 kişilik bir askeri kışla yapılmıştı. Bu nedenle yeni hattın istasyonu Ferecik'teydi ve buradan önceki hatla kasabaya denizden 400 metre uzakta bulunan ilk istasyona geliniyordu. Benzer şekilde bu hattın Selanik'teki istasyonu da güvenlik gerekçesiyle sahilden uzak bir yerde bulunuyordu ve limana bağlanması için ayrıca kısa bir bağlantı hattının yapılması gerekiyordu. Bazı mıntıkalarda da asker için baraka ve hangarların yapımı gecikmişti ve bu durum hattın Osmanlı hükümetince teslim alınmasını geciktirmiştir (Handbook, 1920, s. 44748, 422; Servet-i Fünun, 1312, s. 36-37).

Selanik-Dedeağaç hattının açılmasıyla beraber yukarıda vurgulandığı üzere kent yeni bir canlık kazanır ve Osmanlı imparatorluğundaki gelişmeleri tanıtmaya yönelik gazete yazıları ve hatıratların konusu olur. Bu eserler sayesinde kentin gelişimi, sosyal ve gündelik hayatı üzerine önemli bilgiler edinebilmek mümkündür. $\mathrm{Bu}$ eserlerden ilki kasabaya İstanbul'dan 1891 yılında tren yoluyla gelen Halil Salim Bey'in izlenimleridir. Kasabanın modern kent planına uygunluğu ile taştan yapılmış yeni dükkan ve gazino gibi binalar dikkatini çeker. Mutasarrıf Bahaddin Bey tarafından sahile yakın bir yerde yaptırılan modern hükümet konağını ziyaret ederek Mutasarrıfla görüşür. Mutasarrıfın bu modern kente yakışacak tarza oldukça entelektüel oluğunu ve iyi derecede Fransızca bildiğini anlatır. Ardından kasabada yeni açılan idadi mektebini ziyaret eder. Okulda birkaç sınıfta derse katılır. Öğretmen ve öğrencilerin bilgi ve gayretlerine hayran kalır. Ardından kasabaya ilişkin önemli bilgiler verir. Diğer kaynakların aksine, kasabanın havası ve suyunun çok güzel olduğunu, özellikle limanın Rumeli'nin en önemli limanı olduğunu ve demiryolu sayesinde kentin hızla kalkındığını anlattıktan sonra, askeri açıdan burasının Osmanlı devleti için çok önemli olduğunu vurgular. Eğer liman yapılırsa şehrin servet ve mamuriyetinin daha da artacağını vurgular. Daha sonra İnöz kasabasına giderek, kasabanın Dedeğaç sonrası ekonomik ve sosyal durumuna ilişskin önemli bilgiler verir. İnöz limanın Meriç nehrinin taşıdığı alüvyonlar nedeiyle bir bataklık gibi olduğunu, yelkenli hafif gemilerin bile limana yanaşmakta büyük zorluk yaşadığına şahit olarak, buradaki limanın da bir an önce temizlenmesini önerir. Dedeağaç'ın burayı nüfus ve ekonomik açıdan harap ettiğini de özellikle dikkat çekerek, önlem alınmasını gerektiğini belirtir (Halil Salim 1308, s. 14-25). 
Yazar Dedeağaç Selanik demiryolu hattı inşa edilmeden önce gelmesine rağmen, kasabanın modern görünümü, ticaret ve deniz trafiğinin yoğunluğuna dikkat çekerek, kentin kısa sürede nasıl bir gelişme gösterdiğini biraz abartılı olarak olsa da okuyucularına dikkatle anlatır.

Dedeağaç ile ilgili ikinci en önemli kaynak burada 1896-1899 yılları arasında mutasarrıflık yapan Hazım Bey'in memuriyet hatıratıdır. ${ }^{14}$ Kasaba yeni olduğu için çok önemli bazı kamu binalarının henüz inşaatının başlamadığını veya başlasa bile tamamlanamadığını belirterek ilk önceliğini bu kamu binalarının yapımına verir. Bunlardan, ilk olarak çok büyük eksikliği yaşanan bir hastanenin yapılmasını sağlar. Başta Rumeli Demiryolları şirketi Baron Hirsch'in eşi olmak üzere, vilayet ileri gelenleri ve Selanik’teki Alatini şirketinden yardım alarak, yarısı erkek diğer yarısı da kadınlar için olmak üzere iki yılda tren istasyonuna yakın bir yerde kasabaya bir hastane kazandırır (Hazım, 1925, No: 184). Aynı dönemde hükümet binasının yakınlarına inşa edilmiş olan adliye, jandarma, hapishane, telgrafhane, ziraat bankası ile taş yapı ilk caminin bulunduğu alanı, projesini mühendisler yardımıyla kendisi çizerek küçük bir mülki kampüse dönüştürür. Binaların etrafı duvarla çevrilen bir park içinde alır ve bu avlu içinde binaları birbirine bağlayan yollar yapılır, boşluklar düzeltilerek, ağaç ve çiçekler ekilip güzel bir parka dönüştürülür. Ayrıca hapishaneye su bağlantısı yaptırır, mahkumlara sanat eğitimi sağlayarak onlara meslek kazandırmaya çalışır (Hazım 1925, No: 208).

Hazım Bey'i önemli icraatlarından biri de kasabanın merkezini oluşturan Hamidiye caddesinin sahil kısmında kalan ve Osmanlı devletince demiryolu şirketine istasyon ve liman için tahsis edilen bölgeyi hükümet ve belediyenin kullanımına açması olmuştur. Bu sayede kentin sahil ve liman boyunca genişlemesi mümkün olmuştur. Hazım Bey, kasabanın çarşı ve otellerini barındıran bu kısımda belediye binası dışında bir kamu binasının olmadığını ve bu alanın sadece şirketin tasarrufunda bulunduğunu belirtiyor. Devletin, İstanbul'a rakip olacağı gerekçesiyle limanın inşasını geciktirdiğini, küçük bir mendireğin bulunduğu bu limanı sadece küçük gemiler ile kayıkların kullandığını ve bu nedenlerle de kentin yeterince büyüyemediği tespitinde bulunur. Şirket kasabanın sahil kesiminde gereğinden fazla arsayı elinde tutuğu için bu arsanın 50 bin metrekarelik kısmı onlardan alınarak buralara hükümet daireleri ve okul yapılmış veya hala yapılmaktadır. Geriye kalan 15.000 metre karelik arazi de satışa çıkarılmıştır. Şirket, bu arazide tek veya iki katlı mesken, depo ve oteller yaptırarak kiraya veriyor ve başkalarının bu planın dışına çıkmasına izin vermiyordu. Ayrıca Hamidiye

\footnotetext{
${ }^{14}$ Ebubekir Hazım Tepeyran, (1864-1947), Aslen Niğdelidir. Uzun yıllar pek çok vilayette mutasarrıflık, Şura-yı Devlet üyeliği yaptı. Damat Ferit hükümetinde Bursa Valisi ve Dahiliye Nazırlığı yaptı. Niğde Milletvekili olarak mecliste yer aldı. Şiir, hikaye ve roman yazarıdır (Gök, 2007, s. 202-204).
} 
caddesinde yeniden düzenleme yapılarak yol genişletilir; yaya yolları yapılır ve caddenin iki tarafına çınar ve akasya ağaçları dikilerek başkentte bile olmayan geniş ve ferah bir caddenin inşasına başlanır. Padoma mevkiinden kasabaya içilebilir su getirilmesi için proje yaptırır ve hastaneye su bağlatır (Hazım, 1925, No: 214) ${ }^{15}$.

Hazım Bey Dedeağaç ve art bölgesindeki Bulgar ve Yunan siyasi nüfuz mücadelesi hakkında da önemli bilgiler verir. 1897 Osmanl1-Yunanistan savaşı sırasında Bulgarları hoşnut tutmak ve Yunanistan ile ittifakta bulunmasını engellemek amaciyla Bulgaristan Prensliğinin Edirne, Dedeağaç, Selanik ve Serez gibi Trakya ve Makedonya'nın önemli kentlerine tüccar vekilleri tayin etmesine izin verilmişti. Hazım Bey, bu vekilliklerin kısa bir süre içerisinde konsolos gibi hareket etmeye başladıklarını ve bunların 'Edirne ve Makedonya Bulgar İhtilal Komitesi'nin bu bölgelerdeki temsilcileri gibi hareket ettiklerini, buralarda ciddi örgütlenmelere giriştiklerini anlatır. Dedeağaç’taki Bulgar Tüccar vekilinin bu komitenin politikalarını takip ettiğini gizlice tespit ederek, aldığı istihbaratı delilleriyle birlikte Babıali'ye yollar (Hazım, 1925, No: 186, 213). Bulgar ticaret vekilliğinin bölgede Bulgarca konuşan nüfus üzerinde etkisi ve bunları Bulgar Kilisesi'ne dahil etme faaliyetleri Yunanistan konsolosu ve buradaki Rum ileri gelenlerini de çok rahatsız eder. Dedeağaçlı Rum ileri gelenleri ve aydınları Yunanistan'dan, Bulgarların burada bölgesel yakınlıklarını kullanarak bir Bulgar kimliği yaratma gayretine karşı, Rumların şehirdeki ekonomik üstünlükleri ve etkinliklerini desteklenmesini isterler. Osmanlı Devleti bölgede Yunanistan'a karşı denge olması için Bulgaristan Prensliği’ne bazı konularda göz yummakla beraber, Bulgar çetelerin faaliyetlerini önlemek ve güvenliği sağlamak için gerekli önlemleri de alıyordu (Sarpidon, 1897, s. 316; Bakirtzis, 2019, s. 366). ${ }^{16}$

$\mathrm{Bu}$ dönemle ilgili önemli diğer bir kaynak da Selanik’te öğretmenlik yapan Hüseyin Pertev'in Hazım Bey'in mutasarrıflığının son yılına rastlayan tanıklığıdır ${ }^{17}$. Hüseyin Pertev

\footnotetext{
${ }^{15}$ Görevini devrettikten üç buçuk sene sonra bu projelerinin çoğunun ya tamamlanmadığını, özellikle Hamidiye Caddesi için yapılan planın değiştirilerek caddeni genişliğinin düşürüldüğünü ve parkların bakımsız olduğunu yazar.

${ }^{16}$ Hazım Bey ayrıca Dedeağaç'ın nahiyesi olan Semadirek Adası'yla ilgili oldukça önemli bilgiler verir. Özellikle adada Avusturyalı arkeologların yaptıkları kazılarda çıkardıkları eserleri nasıl Viyana'ya götürdüklerini; Edirne eski Fransız Konsolosunun burada araştırma yaptığını ve bu araşırmada ünlü Semadirek Kanatı Zafer anıtı heykelini bulduklarını, ancak bütün aramalarına heykelin baş kısmını bulamayıp, buraya yollanan Fransız savaş gemisiyle diğer arkeolojik buluntularla birlikte Paris'e götürdüklerini anlatır. Hazım Bey arkeoloji ve fotoğraf meraklısıdır. Bölgede bulduğu veya gördüğü arkeolojik eserlerin fotoğraflarını çektirerek İstanbul Arkeoloji müdürüne yollar. Abdülhamit Fotoğraf Albümünde Dedeağaç’a ait fotoğrafların büyük kısm1 onun tarafından çektirilmiştir. (Hazım, 1925, No: 191)

${ }^{17}$ Hüseyin Pertev Mütalaa gazetesi için Selanik'ten trene binerek, demiryolu hattı üzerinde bulunan bütün kasabaları ziyaret ederek, sonunda Dedeağaç'a ulaşır. Tren yolculuğu sırasında hat üzerindeki Osmanlı kentlerine ilişkin tanıklıklarını ve değerlendirmeleri mektuplar şeklinde Mütalaa gazetesinden 'Dedeağaç Hattı Üzerinde Bir Cevelan' adıyla 13 Ekim 1897 ile 13 Nisan 1898 arasında yayınlanır.
} 
Dedeağaç'a Selanik'ten trenle gelir ve şehri gezip, izlenimlerini Selanik Mütalaa gazetesinde yayınlar. Kenti daha önceden de görmüş olduğu için eski haliyle karşılaştırarak önemli değerlendirmelerde bulunur. Dedeağaç'a ilişkin verdiği bilgiler Hazım Bey’in anılarıyla büyük benzerlikler göstermekte ve onu desteklemektedir. Pertev, Dedeağaç sokaklarının modern kent planlamasına uygun olarak oldukça geniş ve düz olduğunu, cadde üzerindeki evlerin aynı tarzda inşa edildiklerini ve yeni modern kamu binalarının yapıldığını yazarak, kentin modern görünümü çok önemser ve bunu mektuplarında özellikle vurgular. DedeağaçSelanik demiryolu bağlantısının kurulmasının buranın önemini daha artırdığına vurgu yaparak, İstanbul veya Selanik'e gelen veya gidecek yolcuların burayı aktarma noktası olarak kullandıklarını ve bu nedende Dedeağaç otellerinin müşterisiz kalmadıkları ve kasabada yoğun bir yolcu trafiği olduğu bilgisini verir. Pertev, İstanbul-Selanik demiryolu bağlantısı ve küçük limanın yoğun iş hacmine rağmen kasaba nüfusunun istenildiği düzeye gelemediğini ve nüfusu artıracak önlemlerin alınması gerektiğini yazar. Ferecik yakınlarında bulunan kaplıcanın turizme kazandırılmasını ve yeni liman inşasının kasabaya çok büyük katkılarının olacağını belirtir. Ziyareti sırasında Mutasarrıf Hazım Beyle görüşerek kentle ilgili bilgiler alır ve onun Dedeağaç'ın gelişmesi için yaptığı çalışmaları da över (Hüseyin Pertev, 1313/1314). Bu kaynaklar yüzyılın sonunda kentin görümü, ekonomik ve sosyal hayatına ilişkin önemli ilk elden veriler sunmaktadır.

\section{Dedeağaç’ta Sosyo-Ekonomik Yapı ve Ticaret}

1890 yılında Hükümet konağına kavuşan Dedeağaç on yılda bir sancak merkezi için gerekli kamu binalarının çoğuna kavuşmuş, idare ve güvenlik için gerekli alt yapıları oluşmuştu. Kasabada biri idadi olmak üzere toplam 4 okul, 3 kilise ve 1 hastane bulunuyordu. Sancak nüfusu 78.926, kaza nüfusu ise 28.652 kişiye ulaşmıştır. Dedeağaç sancağı, Sofulu, Dimetoka ve İnöz kazaları, Mekri, Ferecik ve İpsala nahiyeleri ile 40 civarında köyden oluşuyordu. Sancak nüfusunda Müslüman ve Rumlar çoğunluğu oluştururken, kaza genelinde Bulgarlar çoğunluktaydı ve bu nedenle de Bulgaristan'ın Ege’ye açılan bu limana özel bir ilgisi vardı. Dedeağaç'ın tren yolu ve gemilerle Rumeli tahıllarının ihraç merkezi olması nedeniyle birisi İnöz'de olmak üzere iki buharlı un fabrikası, birer rakı ve gazoz fabrikalarıyla, tuğla ve kiremit imalathaneleri bulunuyordu. Özellikle Ferecik ve İnöz'deki çömlek imalathanelerinin ürettiği ürünler dışarıdan çok talep görüyordu. Ayrıca kasabanın yakınlarında tren ve vapurların ihtiyacına cevap verebilecek bir kömür madeni de bulunuyordu (Salname, 311, s. 34, 567; Salname, 1319, s. 1070; Annuaire, 1889/90, s. 687; Demirel, 2014, s. 56, 59, 62). 
Dedeağaç limanına 1885 yılında uğrayan buharlı ve yelkenli gemi sayısı 483 iken, bu sayı 1890'da 1.300'e çıkmıştır. Selanik demiryolu hattının da 1896 yılında devreye girmesiyle, limanın ticaret hacmi de artmıştır. 1897 yılında şiddetli dalgalar nedeniyle zarar gören rıhtım, kayık iskelesi ve dalga kıran demir yolu şirketi tarafından tamir edilmiştir. Bu tarihlerde Dedeağaç limanı yaklaşık 61 milyon Franklık bir ihracat hacmine sahipti ki bu tarihlerde İstanbul limanlarının ihracatının 45.5 milyon civarında olduğu göz önüne alınırsa, hala yeterli altyapısı olmayan eski küçük limanın nasıl hızla geliştiği ve bölgenin en büyük ticari limanlarından birisi haline geldiği görülür. Edirne ve Rumeli bölgesinin ihracat kapısı olan bu limandan bölgede ve art alanında üretilen tahıl, kemik, kereste, palamut, şarap, ipek kozas1, yün, deri, balmumu ve yumurta ihraç ediliyordu. Kentte ticaret hacmi yoğun olduğu için bankacılık ve kredi işlemleri için Osmanlı Bankası, Deutsche Orientbank ile Bank de Salonica'nın şubeleri de açılmıştı. (Annuaire, 1912, s. 1410; Temirtsidi, 2009, s. 53-54).

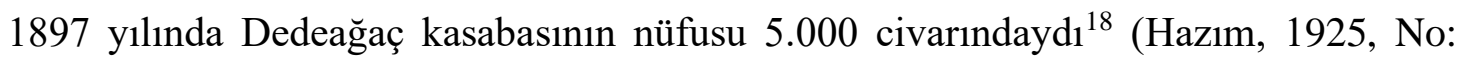
193; Annuaire, 1896, s. 984). Demir ve denizyoluyla başta İstanbul olmak üzere İmparatorluğun ve Avrupa'nın başlıca kentleriyle bağlantısı olan ve ticari açıdan oldukça canlı olan kentin başka kentlerden yeterince nüfus çekememesi, bu tarihlerde kasabayı ziyaret eden Osmanlı aydınlarının ve devlet adamlarının dikkatini çekmiş, bunu limanın inşa edilmemesine bağlamışlardır. Ancak kentin kalbini oluşturan liman ve istasyonun bulunduğu merkez, demiryolu şirketinin elindeydi ve burada başka yapılanmaya izin vermiyordu (Hazım, 1925, No: 214). Kentin hastane, okul gibi sosyal imkanlarının geç oluşması yanında, yeterli içecek suyunun olmaması, yazın sıcaklarda havasının kötü olması ve sıtma hastalığının yaygın olması gibi sıhhi nedenler de burada yeni yerleşimlerin oluşmasını engelliyordu. Kasabadaki nüfusun çoğunluğunu buraya çalışmak için İnöz, Mekri, Edirne gibi yakın çevre ile adalardan gelen Rumlar oluşturuyordu. Demiryolu ile limanda denizcilik ve ticaret işlerinde çalışıyorlardı. Ayrıca Suhor, Misiri, Takela, Hampouri, Efremiadis, Papamihail gibi önde gelen Rum aileler, bölgenin diğer liman kentlerinde de olduğu gibi konsolosluk ve gemi şirketlerinin temsilcilikleri, komisyonculuk ve simsarlık gibi işleri tekellerinde bulunduruyorlard1 (Annuaire, 1896, s. 984; Annuaire, 1912, s. 1410). Kasabada ayrica demiryolu şirketinin inşaat işlerinde çalışmak üzere gelip yerleşen küçük bir Ermeni cemaatiyle çok az sayıda Yahudi de bulunuyordu. Rumlardan sonra nüfusun çoğunluğunu Müslümanlar oluşturuyordu ve iki mahallede yaşıorlardı. Müslümanlar, memurluk, askerlik yanında esnaflık ve ticaret işlerinde, özellikle Rumlarla beraber mavna ve kayık

\footnotetext{
${ }^{18}$ Hazım Bey kasabanın 800 hane ve nüfusunun da 3.500 olduğunu iddia ediyor. Ancak nüfusun bu tarihlerde 5.000 yakın olduğu tahmin ediliyor.
} 
işletmeciliğinde etkindiler. Kasaba da Müslümanlardan sonra üçüncü sırada Bulgar cemaati bulunuyordu. Müslüman ve Rum Cemaatlerinin meclisleri de mevcuttu. Diğer cemaatlerin nüfusları düşük olduğu için cemaat meclisleri bulunmuyordu, sadece sancak genelinde cemaat meclisleri bulunuyordu (Salname, 1306, s. 196, 214).

Dedeağaç limanı hem kasabanın hem de bölgenin en işlek limanlarından biri olup, bölgeden Avrupa ülkelerine ihraç edilen tarımsal ve ticari ham madde ürünlerinin çıkış kapısıydı ve çok sayıda yerli ve yabancı gemi uğruyordu. Dedeağaç yeni bir liman için oldukça uygun olduğundan demiryolu şirketi tarafından Ege’ye açılan kapı olarak seçilmişti. Osmanlı Devleti de demiryolunun inşasından sonra buraya yeni bir liman yapma yükümlüğünü üstlenmişti, bu yatırımı uzun süre gerçekleştiremedi (Hazım, 1925, No: 214). Yeni liman öncesi küçük ölçekli bir yatırımla sadece mavna ve yelkenli küçük gemilerin yararlanabileceği küçük bir iskele ile rıhtım inşa edildi. Bu iskele vasıtasıyla limanın açığına demirleyen buharlı ve büyük yelkenli gemiler yüklerini bu iskeleye mavna veya küçük yelkenli teknelerle boşaltıyor ve alıyorlardı. Bu teknelerin sayısı 70 civarındaydı ve çoğunluğunu Mekri ile İnöz'den gelen Rumların elindeydi, geçimlerini buradan sağlıyorlardı (Hazım, 1925, No: 193; Hüseyin Pertev, 1313/1314; Cochran, 1897, s. 324-325). Dolayısıyla gemilerin yüklerini boşaltmaları ciddi zaman kaybına neden olduğu gibi maliyeti de artırıyordu. Ayrıca Bulgar Prensliği'nin Burgaz'da yaptığı yeni liman Dedeağaç limanını ekonomik olarak da geriletmeye başlamıştı. Burgaz limanının rakip olmaya başlamasıyla beraber Dedeağaç limanının büyük dalga kıranının inşası çalışmalarına 1906 yılında başlanır, ancak 1912'de tamamlanarak işletmeye açılır ve böylece ekonomik açıdan yeniden canlığını kazanmaya başlayarak nüfusu 9.000'e ulaşır (BOA.DH.MKT. 1697/98, H. 1322/M.1906; Hikmet, 19 Eylül 1911; Hastaoğlou, 2010, s. 86-87). Ancak yeni liman yapımıyla Dedeağaç’ta yaşanan bu gelişme uzun sürmez. 1912 yılında Balkan Savaşları sırasında Bulgarlarca işgal edilir ve Osmanlı Devleti’nin elinden çıkar.

\section{Sonuç}

1872 yılında Rumeli demiryollarının Edirne'den Ege Denizi'ne bağlantı noktası olarak seçilen Dedeağaç bölgesi, daha önce herhangi bir yerleşime sahip olmadığg için, demir yolu şirketinin bağlantı hattı ve istasyonu inşaatıyla birlikte ilk yerleşime açılmıştır. Ardından demiryolu ile denizyolu arasındaki yük ve yolcu bağlantısını sağlayan küçük iskele ve rıhtımın inşasıyla hızlı bir şekilde gelişerek 10 yıl gibi kısa bir sürede modern bir liman kentine dönüşmüştür. $\mathrm{Bu}$ yeni liman kenti Avrupa merkezli yeni ekonomik ilişkilerin bölgedeki önemli merkezine dönüşerek art alanında bulunan kasabalar ile Ege adalarından 
denizci ve tüccarları çekmeye başladı. Bunları kısa sürede Avrupa devletlerinin konsolosları, ticaret temsilcileri ile vapur şirketi temsilcileri takip etti. Kentin ticaret erbabı ve demiryolu şirketi kentin modern dönüşümüne ve kent yapısına önemli katkılar sağladı. Kentin sahil kısmında istasyon ve liman bölgesindeki Hamidiye caddesi olarak adlandırılan kesim tek veya iki katlı planlı modern mimari örnekleriyle kentin siluetine Avrupai bir görünüm kazandırmıştı. Oteller, eğlence mekanları ve konsolosluk binaları kentin bu kısmında yer aliyordu.

Bu hızlı ekonomik ve demografik gelişmenin ardından Dedeağaç'ın önce 1876'da kaza, ardından 1884'te sancak ve sancak merkezine dönüştürülmesi, kente beraberinde hükümet, adliye, belediye, hastane, okul, jandarma ve telgrafhane gibi kamu binalarının hızla yükselmesini beraberinde getirerek kentin mekânsal dönüşümünü hızlandırd1. 1890'larda kentin merkezine geniş bulvarlar, parklar inşa edildi, yeni gelen nüfusla beraber kentte yeni mahaller oluştu. Özellikle Selanik-Dedeağaç demiryolu hattının açılması kentin İstanbulSelanik arasında önemli bir durak noktasına dönüştürerek demografik ve mekânsal olarak büyümesine neden oldu. Demiryolları bağlantısı yanında küçük limanı Edirne ve Rumeli bölgesinin tarımsal ve ticari hammadde ürünlerinin Avrupa ve diğer Akdeniz limanlarına ihraç merkezi oldu. Demiryolu hattının inşası sürecinde limanın inşası da planlanmıştı, ancak ekonomik gerekçelerle yapımı gecikti. Bulgaristan'ın Burgaz limanını işletmeye açması, kentin ekonomik canlılığını yitirmesi neden olunca Osmanlı devleti 1912 yılında limanın inşaatı tamamladı. Ancak kent daha yeni limanın meyvelerini toplayamadan Balkan Savaşları patlak verdi ve Dedeağaç Osmanlı egemenliğinden bir daha geri dönmemek üzere çıktı. 1872'de bataklıkların arasında, susuz ve 1ssız bir sahil şeridinde doğan yeni liman kenti, ekonomik ve demografik açıdan eski Roma Egnatia (Sol kol) yolu üzerinde bulunan Mekri ve Ferecik ile bölgenin eski liman kasabası İnöz'un gerilemesi ve önemini kaybetmesine de neden olmuştur. 
Aydın, H. V. (2021). Rumeli demiryolları Ege Denizi bağlantı hattında yeni bir liman kenti: Dedeağaç (1872-1912). Humanitas, 9(17), 76-100

\section{Kaynakça}

Ahmet Badi Efendi (2014). Riyad-ı belde-i Edirne: 20. yüzyıla kadar Osmanlı Edirne'si. C 3, (1. bask1). N. Adıgüzel ve R. Gündoğdu (Haz.). Edirne: Trakya Üniversitesi.



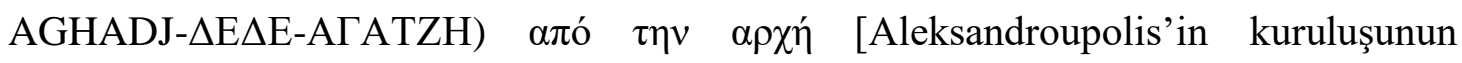
hayranlık uyandıran tarihi]. http://alepakos.blogspot.com/2017/10/dede-aghadj.html

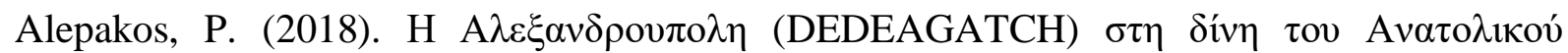
$\zeta \eta \tau \dot{\mu} \mu \alpha \tau$ [Şark meselesi girdabında Aleksandroupolis (DEDE-AGATCH)] http://alepakos.blogspot.com/2018/10/dedeagatch.html

Ali Saib (1304). Coğrafya-i mufassal-i memalik-i devlet-i Osmaniye. Konstantiniye: y.y.

Annuaire (1881). L'indicateur Ottoman: Annuaire-almanach du commerce. Contantinople: Cervati Freres.

Annuaire (1883). L'indicateur Ottoman: Annuaire-almanach du commerce. Contantinople: Cervati Freres.

Annuaire (1885/1886). L'indicateur Ottoman: Annuaire-almanach du commerce. Contantinople: Cervati Freres.

Annuaire (1896). L'indicateur Ottoman: Annuaire-almanach du commerce. Contantinople: Cervati Freres.

Annuaire (1889/1890). L'indicateur Ottoman: Annuaire-slmanach du commerce. Contantinople: Cervati Freres.

Annuaire (1912). L'indicateur Ottoman: Annuaire-almanach du commerce. Contantinople: Cervati Freres.

Aydın, H. V. (2020). A port city at the backyard of İstanbul: Rodoscuk (Tekirdağ) in the 19th century. E. Gavra \& E. Georgitsoyanni, Port cities and maritime routes in the Eastern Mediterranean and Black Sea, 18th-21st (1st ed.) in (pp. 3-25). Thessaloniki: University of Macedonia.



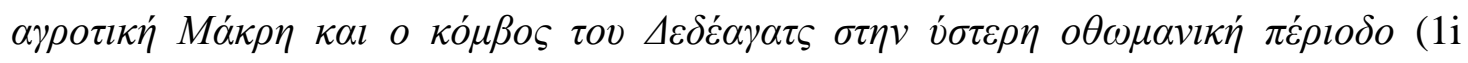
Ekdosi) [Dönüşen Güney Meriç (19. yüzyılın sonları-20. yüzyılın başları), geç Osmanlı döneminde tarım kenti Mekri ve Dedeağaç kavşağı]. Thessaloniki: Ekdosis Stamouli

Başbakanlık Osmanlı Arşivleri (BOA).HR.SYS. 232/12. 
Başbakanlık Osmanlı Arşivleri (BOA).İ̧SD. 69/4091.

Başbakanlık Osmanlı Arşivleri (BOA).ŞD. 190/52.

Başbakanlık Osmanlı Arşivleri (BOA).ŞD. 2883/12.

Başbakanlık Osmanlı Arşivleri (BOA).ŞD. 2885/30/1.

Başbakanlık Osmanlı Arşivleri (BOA).BOA. SAİD.d. 4/398.

Başbakanlık Osmanlı Arşivleri (BOA).DH.1229/96204.

Başbakanlık Osmanlı Arşivleri (BOA).DH.MKT. 1697/98.

Başbakanlık Osmanlı Arşivleri (BOA).DH.MKT.1429/83.

Başbakanlık Osmanlı Arşivleri (BOA).DH.MKT.1676/69.

Başbakanlık Osmanlı Arşivleri (BOA).DH.MKT.1791/2.

Başbakanlık Osmanlı Arşivleri (BOA).HR.SYS.1341/76.

Başbakanlık Osmanlı Arşivleri (BOA).HR.SYS.232/12.

Başbakanlık Osmanlı Arşivleri (BOA).MKT.MHM.449/4,14.

Başbakanlık Osmanlı Arşivleri (BOA).PLK.P.4238.

Başbakanlık Osmanlı Arşivleri (BOA).PLK.P.5083.

Başbakanlık Osmanlı Arşivleri (BOA).ŞD.2885/30/1.

Başbakanlık Osmanlı Arşivleri (BOA).Y.MTV.133/15.

Başbakanlık Osmanlı Arşivleri (BOA).Y.MTV.326/6.

Başbakanlık Osmanlı Arşivleri (BOA).Y.PRK.AZJ. 2/31.

Başbakanlık Osmanlı Arşivleri (BOA).Y.PRK.TNF. 24/49.

Başbakanlık Osmanlı Arşivleri (BOA).Y.PRK.TNF.2/7.

Cochran, W. (1887). Pen and pencil in Asia Minor (1st ed.). London: Sampson Low, Marston, Searle and Rivington.

Dede-ağaç (1978). Dede-ağaç, MEB İslam Ansiklopedisi, 3, 500.

Demirel, F. (2014). Batı Trakya'da Osmanlı eğitim kurumları. History Studies, 6(2), 53-65.

Engin, V. (1993). Rumeli demiryollarl (1. bask1). İstanbul: Eren.

Engin, V. (2008). Rumeli Demiryolları, TDV İslam Ansiklopedisi. 35, 235-237.

Evliya Çelebi (2003). Evliya Çelebi seyahatnamesi (1. baskı). C 8, A. Kahraman vd. (Haz.). İstanbul: Yapı Kredi Yayınları. 
Aydın, H. V. (2021). Rumeli demiryolları Ege Denizi bağlantı hattında yeni bir liman kenti: Dedeağaç (1872-1912). Humanitas, 9(17), 76-100

Furat, A. Z. (2013). Berlin Anlaşması sonrasında Balkanlar'da Cemaat-i İslamiyelerin teşekkülü (1878-1918). Ankara Üniversitesi Osmanlı Tarihi Araştırma ve Uygulama Merkezi Dergisi, 33, 63-93.

Gök, N. (2007). Ebubekir Hazım Tepeyran'ın memleket idaresine dair, Ankara Üniversitesi Dil Tarih Coğrafya Fakültesi Tarih Dergisi, 26(42), 201-215.

Gökbilgin, T. (1991). Dede Agach, Encyclopedia of Islam, 2, 200.

Hastaoglou-Martinidis, V. (2010). The cartography of harbor construction in Eastern Mediterranean cities: Technical and urban modernization in the late nineteenth century. B. Kolluoğlu \& M. Toksöz (Eds.), Cities of the Mediterrenean: from Ottomans to the present day (1st ed.) in (pp. 78-100). London-Newyork: I.B. Tauris.

Hüseyin Pertev (1313-1314). Dedeağaç hattı üzerinde bir cevelan, Dedeağaç hatıratı. Mütaala, (62-89).

Hazım, T. (1925). Memleket hatıraları, İctihad, 15 Temmuz 1925-15 Eylül 1926, No: 184,186, 191,193, 208, 213, 214.

İlhan, E. (Haz.). (2016). Lale Devrinde gül aşı̆̆ı: III. Ahmed (Necîb)-hayatı, sanatı ve divançesi (1. baskı). Ankara: Gece Kitaplığı.

Jelavich, B. (2009). Balkan tarihi: 18. ve 19. yüzyıllar (3. baskı), (İ. Durdu ve ark. Çev.), C I. İstanbul: Küre Yayınları (Orijinal çalışma basım tarihi 1999).

Karal, E. Z. (2000). Osmanlı tarihi, C 8, (5. bask1). Ankara: Türk Tarih Kurumu.

Keyder, Ç. (2010). Port-cities in the Belle Epoque, B. Kolluoğlu \& M. Toksöz (Eds.), Cities of the Mediterrenean: From Ottomans to the present day (1st ed.) in (pp. 14-28). London-Newyork: I. B. Tauris.

Kiel, M. (1995). Ferecik. TDV İslam Ansiklopedisi, 12, 371-373.

Mehmet Cavid (1324). Rumili şimendiferleri, Ulum-i İktisadiye ve İctimaiye Mecmuası, 1(1), 78-120.

Neologos, No: 4590, 30 Ağustos 1884.

Salname (1287). Salname-i Vilayet-i Edirne, Defa 1, Edirne: Vilayet Matbaas1.

Salname (1291). Salname-i Vilayet-i Edirne, Defa 5, Edirne: Vilayet Matbaas1.

Salname (1293). Salname-i Vilayet-i Edirne, Defa 8, Edirne: Vilayet Matbaas1.

Salname (1301). Salname-i Vilayet-i Edirne, Defa 10, Edirne: Vilayet Matbaas1.

Salname (1302). Salname-i Vilayet-i Edirne, Defa 11, Edirne: Vilayet Matbaas1. 
Aydın, H. V. (2021). Rumeli demiryolları Ege Denizi bağlantı hattında yeni bir liman kenti: Dedeağaç (1872-1912). Humanitas, 9(17), 76-100

Salname (1305). Salname-i Vilayet-i Edirne, Defa 14, Edirne: Vilayet Matbaas1.

Salname (1306). Salname-i Vilayet-i Edirne, Defa 15, Edirne: Vilayet Matbaası.

Salname (1310). Salname-i Vilayet-i Edirne, Defa 20, Edirne: Vilayet Matbaas1.

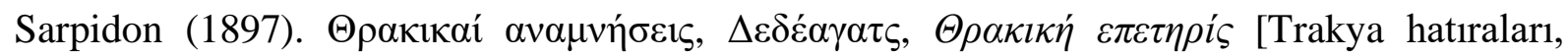
Dedeağaç, Trakya yıllı̆̆g]. Athinai: Thrakikis Adelfotitos, s. 310-318.

Servet-i Fünun (1312). Servet-i Fünun. 11(286), No: 360, 23 Mart 1312.

Şemseddin Sami (1308). Kamusu'l-alam: Tarih ve coğrafya lügâtı, C 3. İstanbul: Mihran Matbaas1.

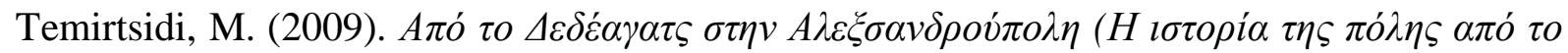
1860 to 1920) [Dedeağaç'tan Aleksandroupolis'e (1860'dan 1920'ye bir kentin tarihi], (Yayınlanmamış yüksek lisans tezi). Thessaloniki: Aristotelio Panepistimiou Thessalonikis.

Tozer, H. F. (1890). The islands of Aegean (1st ed.). Oxford: Claredon Press.

Tuğlac1, P. (1985). Osmanlı şehirleri (1. bask1). İstanbul: Milliyet.

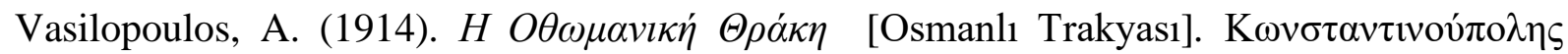
[Konstantinoúpolis]: Typografio Adelfon Gradon. 